\title{
KULLANMA ZIMMETI
}

\section{Ahmet Hulusi AKKAŞ Eren AKPINAR **}

\section{$\ddot{O} Z$}

Kullanma zimmeti TCK m. 247/3 'te tanımlanmıştır. Buna göre zimmet suçunun malın geçici bir süre kullanıldıktan sonra iade edilmek üzere işlenmesi halinde, verilecek ceza yarı oranına kadar indirilebilir. Hukukumuzda ilk defa 5237 sayıl TCK'da açıkça kanuni bir zemine kavuşturulan kullanma zimmetinin cezası, zimmet suçuna göre belirlenmiştir. Kanunda kullanma zimmeti, zimmet suçunun daha az ceza verilmesini gerektiren bir nitelikli hali olarak düzenlenmiştir. Zimmete konu malın iade edilmek üzere alınması ve geçici bir süre için kullanılması durumunda, kullanma zimmetinden bahsedilecektir.

Kullanma zimmeti, daha az ceza verilmesini gerektiren bir nitelikli hal olarak düzenlendiği için zimmet suçu açısından geçerli olan durumların hepsinin kullanma zimmetinde de söz konusu olması gerekir. Bu kapsamda örneğin, kullanılan malın değerinin azlı̆̆l, faile daha az ceza verilmesiyle sonuçlanır.

Anahtar Kelimeler: Zimmet, Kullanma Zimmeti, Nitelikli Hal, Türk Ceza Kanunu, Kати Görevlisi

\section{EMBEZZLEMENT TO USE}

\section{Abstract}

"Embezzlement to use" is defined in the article 247/3 of Turkish Penal Code (TPC). According to this, had the crime of embezzlement is committed to return the property after temporary use, the penalty to imposed can be reduced by half. In Turkish Law, the punishment of embezzlement to use, which was given a legal basis in TPC No. 5237 explicitly for the first time, was determined according to the crime

* Dr. Öğr. Üyesi, Erciyes Üniversitesi Hukuk Fakültesi Ceza ve Ceza Muhakemesi Hukuku Anabilim Dalı/ KAYSERİ, e-posta: ahakkas@erciyes.edu.tr,

ORCID : 0000-0001-5217-5951

** Arş. Gör., Erciyes Üniversitesi Hukuk Fakültesi Ceza ve Ceza Muhakemesi Hukuku Anabilim Dalı/ KAYSERİ, e-posta: erenakpinar@erciyes.edu.tr,

ORCID : 0000-0002-4206-995X

DOI : :10.34246/ahbvuhfd.933588

\section{Yayın Kuruluna Ulaştığı Tarih $\quad$ : 19/12/2020}

Yayınlanmasının Uygun Görüldüğü Tarih: 16/04/2021

Ankara Hacı Bayram Veli Üniversitesi Hukuk Fakültesi Dergisi C. XXV, Y. 2021, Sa. 2465 
of embezzlement. In TPC, it is regulated as a qualified form of embezzlement that requires less punishment. The embezzlement to use is discussed in the cases that the property is taken for return and used for a temporary period.

Since the crime of embezzlement to use is regulated as a qualified form of embezzlement that requires less punishment, all circumstances that are valid in terms of crime of embezzlement must also be in effect in the embezzlement to use. Within this context, for instance, the low value of the property used must result in less punishment for the perpetrator.

Keywords: Embezzlement, Embezzlement to Use, Qualified Form, Turkish Penal Code, Public Official

\section{Giriș}

TCK m. 247'de görevi nedeniyle zilyetliği kendisine devredilmiş olan veya koruma ve gözetimiyle yükümlü olduğu malı kendisinin veya başkasının zimmetine geçiren kamu görevlisinin cezalandırılacağı düzenlenmiştir. İlgili maddenin üçüncü fikrasında ayrıca zimmet suçunun malın geçici bir süre kullanıldıktan sonra iade edilmek üzere işlenmesi durumunda faile daha az ceza verileceği hüküm altına alınmıştır. Kullanma zimmeti olarak adlandırılan bu durum, 765 sayılı TCK döneminde gerek yargı kararlarında gerek öğretide tanınsa da ilk defa 5237 sayılı TCK'da açıkça kabul edilmiştir.

Kullanma zimmeti, zimmet suçunun daha az ceza verilmesini gerektiren nitelikli bir hali olarak düzenlenmiştir. Sadece kullanma zimmeti ile ilgili açıklamalarda bulunacağımızdan, çalışmamızı klasik bir suç tipi incelemesi şeklinde yapmaktan kasıtlı olarak kaçındık. Konunun anlaşılabilmesi için kısa da olsa 765 sayılı TCK döneminden bahsettik. Bir suç tipi incelemesinde olmazsa olmaz hususlardan birisi kanunda yer alan soyut suç düzenlemesinin uygulamaya nasıl yansıdığıdır. Bu nedenle çalışmamızda konuya ilişkin Yargıtay kararlarına sıklıkla yer vermeye çalıştık.

\section{Genel Olarak Zimmet Suçu}

Zimmet suçu ve bu suçun nitelikli halleri, 5237 sayılı TCK'nın “Özel Hükümler" başlıklı ikinci kitabının "Millete ve Devlete Karşı Suçlar ve Son Hükümler" başlıklı dördüncü kısmının "Kamu İdaresinin Güvenilirliğine ve İşleyişine Karşı Suçlar”'1n düzenlendiği birinci bölüm m. 247’de, “ (1) Görevi nedeniyle zilyedliği kendisine devredilmiş olan veya koruma ve gözetimiyle 
yükümlü olduğu malı kendisinin veya başkasının zimmetine geçiren kamu görevlisi, beş yıldan oniki yıla kadar hapis cezası ile cezalandırılır.

(2) Suçun, zimmetin açığa çıkmamasına yönelik hileli davranışlarla işlenmesi halinde, verilecek ceza yarı oranında arttırllır.

(3) Zimmet suçunun, malın geçici bir süre kullanıldıktan sonra iade edilmek üzere işlenmesi halinde, verilecek ceza yarı oranına kadar indirilebilir" şeklinde düzenlenmiştir.

Türk Dil Kurumu Türkçe Sözlükte "zimmet”, "üstünde olan şey; kurum ve kuruluşlarda çalışanlara veya para işleri ile uğraşan görevliye imza karşıllı̆ 1 teslim edilen para veya eşya; bir kimsenin yasal olmayan yollardan üzerine geçirip ödemeye zorunlu olduğu para; bir ticaret kuruluşunun borçlarının tümü” olarak tarif edilmiştir ${ }^{1}$. Hukuki anlamda ise TCK m. 247/1'de de belirtildiği üzere kamu görevlisinin, görevi nedeniyle zilyetliği kendisine devredilmiş olan veya koruma ve gözetimiyle yükümlü olduğu malı kendisinin veya bir üçüncü kişinin mülkiyetine geçirmesi olarak tarif edilebilir.

Türk Ceza Kanunu m. 247/1'de zimmet suçunun temel şekli, ikinci fikrada daha ağır cezayı gerektiren nitelikli hali ve üçüncü fikrada ise daha az cezayı gerektiren nitelikli haline yer verilmiştir². Söz konusu düzenleme dışında ayrıca TCK m. 248'de zimmet suçuna ilişkin etkin pişmanlık hükmü yer alırken ${ }^{3}, \mathrm{~m}$. 249'da zimmet suçunun konusunu oluşturan malın değerinin azlığ 1 haline yer verilmiştir ${ }^{4}$.

Zimmet suçu, kamu görevlisi tarafından işlenebilen, bir anlamda güveni kötüye kullanma suçunun özel bir şeklidir ${ }^{5}$. Suç, özgü bir suçtur; fail,

1 Türk Dil Kurumu Türkçe Sözlük, <https://sozluk.gov.tr/> Erişim Tarihi 11 Aralık 2020.

25237 sayılı TCK'da suçun nitelikli hallerinin hem cezayı ağırlaştıran hem de cezayı hafifleten sebepler olarak düzenlendiği konusunda bkz. İzzet Özgenç, Türk Ceza Hukuku Genel Hükümler, 16. Bası, Seçkin Yayıncılık, 2020, s.227 vd; ayrıca bkz. Mahmut Koca ve İlhan Üzülmez, Türk Ceza Hukuku Genel Hükümler, 12. Bask1, Seçkin Yayıncılık, 2019, s. 139 vd.

3 Etkin pişmanlığın 5237 sayılı TCK'da suç tamamlandıktan sonra gösterilen bazen cezayı kaldıran bazen de cezada indirim yapılmasını gerektiren bir hal olarak düzenlendiği görüşü için bkz. Özgenç, Genel Hükümler, s. 699 vd.

4 Zimmet suçunda suç konusu malın değerinin azlığına ilişkin açıklama için bkz. Ahmet Hulusi Akkaş, "Suç Konusu Malın Değerinin Azlığının Ceza Sorumluluğuna Etkisi", 2018, 9(1), İnönü Hukuk Fakültesi Dergisi, s. 335 vd., <https://dergipark.org.tr/tr/pub/inuhfd/issue/33699/407978> Erişim Tarihi 9 Ekim 2020.

5 İzzet Özgenç, Zimmet Suçu, 2. Bası, Seçkin Yayıncılık, 2012, s. 13. 
kamu görevlisidir. Suçun oluşabilmesi için failin görevi nedeniyle zilyedliği kendisine devredilmiş olan veya koruma ve gözetimiyle yükümlü olduğu malı zimmetine geçirmesi gerekir. Zimmete geçirilen herhangi bir mal değil, kamu görevlisine görevi nedeniyle zilyetliği devredilmiş olan ya da koruma ve gözetimi altındaki mal olduğundan; önce zilyetliğin devri kavramının açıklanmasının faydalı olacağı kanısındayız ${ }^{6}$.

Zilyetliğin devri, kamu idaresi ya da üçüncü bir kişi tarafından, hür bir iradeyle malın kamu görevlisinin hâkimiyet alanına bırakılmasıdır ${ }^{7}$ Devrin resmen gerçekleştirilmesi gerekmese de kamu görevlisinin mal üzerinde görevi sebebiyle zilyet konumunda olması gerekir8. Görevlendirme olmasina rağmen kamu görevlisinin görev mevzuatı gereğince malın zilyetliğinin devrini kabule yetkili olmaması halinde, fiil zimmet suçuna sebebiyet vermeyecektir?

Zimmet suçuna konu mal, kamu görevlisinin koruma ve gözetimiyle sorumlu olduğu mal da olabilmektedir. Zilyetliği devredilmiş malda olduğu gibi koruma ve gözetim yükümlülüğünün, kamu görevlisinin görevi sebebiyle doğmas1 gerekmektedir ${ }^{10}$. Kamu görevlisinin görevlendirilmesinin, yasal

6 Nur Centel, "Zimmet Suçu”, 2019, 21(Özel Say1), Dokuz Eylül Üniversitesi Hukuk Fakültesi Dergisi, Prof. Dr. Durmuş Tezcan'a Armağan, s. 2789, <https://hukuk.deu.edu.tr/cilt-21ozel-sayi-2019/> Erişim Tarihi 15 Ekim 2020.

7 Mahmut Koca ve İlhan Üzülmez, Türk Ceza Hukuku Özel Hükümler, 7. Bask1, Seçkin Yayincilik, 2020, s. 973.

8 Nevzat Toroslu, Ceza Hukuku Özel Kısım, 10. Baskı, Savaş Yayınevi, 2019, s. 281.

9 Mehmet Emin Artuk ve Ahmet Gökcen, Ceza Hukuku Özel Hükümler, 19. Bask1, Adalet Yayınevi, 2021, s. 1026; Toroslu, s. 281; Aksi yönde görüş için bkz. Özgenç, Zimmet, s. 16; Bu kapsamda örneğin 5188 sayılı "Özel Güvenlik Hizmetlerine Dair Kanun" m. 16'da özel güvenlik personelinin, kanunda belirtilen koruma ve güvenlik hizmetleri dışında başka bir işte çalıştırılamayacağı açık bir şekilde düzenlenmiştir. Dolayısıyla kanuna aykırı bir şekilde örneğin bir bankanın veznesinde görevlendirilen özel güvenlik görevlisi, kendisine fiili olarak emanet edilen paraları kendisinin veya bir üçüncü kişinin zilyetliğine geçirmiş olsa bile zimmet suçundan dolayı sorumlu olmaz. Konuya ilişkin Yargıtay'ın vermiş olduğu bir kararının ilgili kısmı şu şekildedir: "Sanığın müdahil bankanın 03.06.2004 tarihli yazısında belirtildiği gibi, şubede koruma görevlisi olarak çalıştığ 1 , şifresinin bulunmadığı, para tahsil ve tediye yetkisinin olmadığ gari düzeye indirmek için genel müdürlüğün onayı olmaksızın şubece resen görevlendirildiği dosya kapsamından anlaşılmakla, 5188 sayılı Özel Güvenlik Hizmetlerine dair Kanunun 16.maddesi uyarınca güvenlik görevlilerinin koruma ve güvenlik hizmetleri dışında başka işte çalıştırılamayacağı cihetle, sanığın üzerine atılı eylemin zimmet suçunu oluşturmayacağı gözetilmeden beraati yerine yazılı şekilde mahkumiyet hükmü kurulması", Yargıtay 7. CD, 20.10.2011 tarih ve E. 2008/13230 K. 2011/19532 sayılı kararı, <http://www.kazanci. com/kho2/ibb/giris.html> Erişim Tarihi 12 Aralık 2020. 
bir engel olmadığ1 sürece yazılı şekilde yapılması ile amiri tarafından sözle görevlendirilmesi bakımından bir fark bulunmamaktadır. Hatta kamu personelinin herhangi bir görevlendirme olmadan, fiilen para tahsili yaptığ 1 hallerde de mal edinme eylemleri zimmet kapsamında kabul edilmelidir ${ }^{11}$. Ancak bütün bu hallerde, yerine getirilen görevle malın zilyetliğinin devri arasında nedensellik ilişsisi kurulabilmelidir ${ }^{12}$.

Zimmet suçunun maddi unsurunu, zimmete geçirme oluşturmaktadır ${ }^{13}$. Zimmete geçirme, failin zilyetliğindeki mal üzerinde malik gibi tasarrufta bulunmasını ifade eder. Tasarruf, suça konu şeyin mal edinilmesi, amacı dışında kullanılması, tüketilmesi şeklinde olabileceği gibi malın bir başkasına satılması veya verilmesi şeklinde de olabilir. Bu kapsamda zimmete geçirme eylemini, failin mal edinmesi veya malda tahsis edildiği amacı dışında tasarrufta bulunması şeklinde özetleyebiliriz.

Suçun konusunu, ekonomik değeri olan herhangi bir mal oluşturur. 765 sayılı TCK'daki düzenlemenin aksine, mal kavramı kullanılarak daha kapsayıcı bir kelime tercih edilmiştir ${ }^{14}$. Zimmete konu malın maliki, kamu idaresi olabileceği gibi üçüncü bir kişi de olabilir.

\section{Korunan Hukuki Değer}

Hukukumuzda kullanma zimmeti, zimmet suçunun işleniş şekli itibariyle daha az ceza verilmesini gerektiren bir nitelikli hali olarak düzenlenmiştir. Dolayısıyla korunan hukuki değer yönünden, zimmet suçunun esas alınması gerekmektedir.

11 "Görevlendirilmesine yasal engel bulunmayan sanığın, sözlü olarak verilen görevi itirazsız olarak yerine getirdiğinin kabul edilmesi karșısında Dairemizin istikrar kazanmış uygulamalarına göre eyleminin zincirleme biçimde nitelikli zimmet suçunu oluşturacağı gözetilmeden suç vasfinda yanılgıya düşülerek yazılı şekilde hüküm tesisi”, Yargıtay 5.CD, 29.11.2012 tarih ve E. 2012/11457 K. 2012/12272 sayılı kararı için bkz. İhsan Akçin, Kamu İdaresinin Güvenilirliğine ve İşleyişine Karşı Suçlar, 2. Bask1, Adalet Yayınevi, 2019, s. 178.

"Suç tarihi itibariyle suça konu işlemlere ilişkin olarak sanığın tahsilat yapma yetkisinin olup olmadığı, fiilen ya da yazılı olarak tahsilat işi ile görevlendirilip görevlendirilmediğinin araştırılması, tahsilat yetkisi bulunmadığı takdirde eylemlerinin mağdur sayısında ikna suretiyle irtikap ve zincirleme resmî belgede sahtecilik suçlarını, tahsilat yetkisinin varlığ halinde zincirleme nitelikli zimmet suçunu oluşturacağı", Yargıtay 5.CD, 03.06.2013 tarih ve E. 2013/8932 K. 2013/6062 say1l kararı için bkz. Akçin, s.179.

12 Koca ve Üzülmez, Özel Hükümler, s. 971.

13 Centel, s. 2788

14765 Sayılı TCK'da mal kavramı yerine para, para yerine geçen evrak veya senetleri, diğer mallar ifadesi kullanılmaktaydı. 5237 sayılı TCK' da bütün bunları kapsayacak bir kelime olan "mal" ifadesi tercih edilmiştir. 
Öğretide zimmet suçuyla korunan hukuki değerin ne olduğunun izahı bakımından farklı görüşler ortaya atılmaktadır. Bir görüşe göre zimmet suçuyla korunan hukuki değer, devletin mali menfaatleridir ${ }^{15},{ }^{16}$. Bir diğer görüşe göre zimmet suçuyla toplum nezdindeki kamu görevlilerine duyulan güven duygusu korunmaktadır ${ }^{17}$. Bir başka görüşe göre ise zimmet suçuyla birden fazla hukuki değer korunmaktadır. Buna göre zimmet suçu ile kamu görevlilerinde olması gereken doğruluk, dürüstlük ve devlete karşı sadakat yükümünün gerekliliği ile ayrıca kamu idaresinin iyi işlemesi ve mali menfaatleri korunmaktadir ${ }^{18}$.

Kanaatimizce ikinci görüş çerçevesinde, zimmet suçuyla korunan hukuki değerin kamu görevlilerinin yükümlülükleri kapsamında hareket edeceklerine dair toplum nezdindeki güvenin korunması olduğunu düşünmekteyiz. Kamu görevi, tüm bireyler adına kamu görevlileri aracılığıyla gerçekleştirilen bir faaliyettir ${ }^{19}$. Toplumda, kamu görevlilerinin bu faaliyetleri yükümlülükleri dahilinde yerine getireceklerine dair bir güven duygusu bulunmaktadır ve kamu görevlilerinin de bu düşünceye zarar verecek fiillerde bulunmamaları gerekir $^{20}$. Zarar verecek hareketlerin cezalandırılması, düzenin korunması için önemlidir. Çünkü kamu idaresinin dürüst bir şekilde işlediği, mutlak ve

15 Sulhi Dönmezer, Özel Ceza Hukuku Dersleri, Fakülteler Matbaası, 1984, s. 76.

16 Kanaatimizce suçla korunan hukuki değerin devletin mali menfaatleri olduğunun kabulü, zimmeti özgü suç statüsünden çıkaracaktır. Bu durum suçun herhangi bir kişi tarafından işlenebilmesine imkân verecek ve zimmet suçunun kalpazanlık, milletin kredisine zarar verme, devlete ait araçları tahrip gibi suçlarla birlikte düzenlenmesini de gerektirecektir. Ayrıca bu görüşün kabulünün, zimmetin ayrı bir suç tipi olarak düzenlenmesini gereksiz hale getireceği, kanun koyucunun bu suça olan ihtiyacı mala karşı suçlarda yer vereceği nitelikli hallerle (ağırlaştırıcı neden) giderebileceğine ilişkin görüş için bkz. Güneş, Okuyucu Ergün, Türk Hukukunda Zimmet Suçu, 1. Bası, Çakmak Yayınevi, 2008, s. 67.

17 İlhan, Üzülmez, "Yeni Türk Ceza Kanunu'nda Zimmet Suçu”, 2005, (5), Hukuki Perspektifler Dergisi, s.218; Özgenç, Zimmet, s. 13; Artuk ve Gökcen, s. 1014; Koca ve Üzülmez, Özel Hükümler, s. 968; Suçla korunan hukuki değerin kişilerin kamu idaresine ve işleyişine karş1 mevcut güveninin korunması olduğunu belirten görüş için bkz. Akçin, s. 27;

18 Durmuş Tezcan, Mustafa Ruhan Erdem ve R. Murat Önok, Teorik ve Pratik Ceza Özel Hukuku, 18. Bask1, Seçkin Yayıncılık, 2020, s. 1249; Doğan Soyaslan, Ceza Hukuku Özel Hükümler, 12. Baskı, Savaş Yayınevi, 2019, s. 697; Toroslu, s. 280; 5237 sayılı TCK'daki yaklaşımın da bu yönde olduğu ve kamu idaresine olan güvenin ve düzenli işleyişin korunmasının doğal sonucu olarak idarenin mali menfaatlerinin de korunacağına ilişkin görüş için bkz. Okuyucu Ergün, s. 69.

19 Özgenç, Zimmet, s. 11; Koca ve Üzülmez, Özel Hükümler, s. 968.

20 İzzet Özgenç, Ekonomik Çıkar Amacıyla İşlenen Suçlar, 1. Baskı, Seçkin Yayıncılık, 2002, s. 134. 
vazgeçilmez bir olgudur ${ }^{21}$. Olgunun sürdürülebilirliği, kamu görevlilerinin yükümlülükleri doğrultusunda görevlerini yerine getirmesiyle korunabilir. Zimmete geçirme eyleminin ise toplumda kamu görevlilerine duyulan güvene zarar vereceği açıktır ${ }^{22}$. Ancak bu zarar, zimmete geçirilen malın kamu idaresinin mali menfaatlerine zarar vermesinden çok; kamu görevlisinin görevinin gerektirdiği yükümlülüklere aykırı hareketinden doğmaktadır. Zimmete geçirilen mal, kamu idaresinin mali menfaatleri bakımından asli bir önem arz etmez. Hatta zimmet suçu bakımından malın mülkiyetinin kamu idaresine veya üçüncü bir kişiye ait olması bakımından dahi bir ayrım yapılmamıştır. Dolayısıyla zimmet suçu ile korunması hedeflenen hukuki değerin ayrıca kamu idaresinin mali menfaatleri de olduğu görüşüne katılmamaktayız.

Suçun cezalandırılmasının doğal bir sonucu olarak kamu idaresinin mali menfaatleri korunmuş olsa da bu suçla asıl hedeflenen şey, toplumdaki kamu görevlisine duyulan güvenin korunmasıdır. Nitekim 5237 sayılı TCK'da zimmet suçunun "Kamu İdaresinin Güvenilirliğine ve İşleyişine Karşı Suçlar" isimli başlıkta düzenlenmesi de bu görüşü destekler niteliktedir.

Kullanma zimmeti özelinde korunan hukuki değere bakacak olursak; kullanma zimmetinde failin, söz konusu malı mülkiyetine geçirme gibi bir amacı yoktur. Hatta kullanma zimmetiyle beraber çoğu zaman kamu idaresinin işleyişi ve mali menfaatleri açısından büyük bir zarar dahi doğmamaktadır. Bu durum kullanma zimmetinin, zimmet suçunun temel şekline nazaran daha az cezalandırılmasının bir nedenidir. Ancak daha az cezayı gerektiren bir nitelikli hal olmasına rağmen kullanma zimmetinin cezalandırılması, toplumdaki kamu görevlisine olan güvenin korunması açısından önemlidir. Kamu görevlisinin görevi sebebiyle kendisine bırakılmış olan malı, bu tahsis amacının dışında kendi hususi işlerinde kullanması, toplumda kamu görevlisine karşı duyulan güven duygusunu zedelemektedir.

\section{III.765 Sayılı TCK Döneminde Kullanma Zimmeti}

765 sayılı TCK döneminde açıkça düzenlenmeyen ancak doktrinde "kullanma zimmeti" olarak adlandırılan durum, Yargıtay içtihatlarıyla ortaya konulmuştur ${ }^{23}$. Bu dönemde doktrinde hâkim olan görüş; görevi sebebiyle

\footnotetext{
21 Akçin, s. 27

22 Centel, s. 2785.

23 "Mudilerin hesaplarındaki paraları onlardan habersiz çekip kullandıktan sonra aynı hesap-
} 
kendisine zilyetliği devredilmişolan veya koruma ve gözetimi altındakieşyanın, kamu görevlisi tarafından geçici bir süreyle hususi işlerde kullanılmasının zimmet suçunu oluşturmayacağı yönündeydi ${ }^{24}$. Kullanma hırsızlığından ilham alınarak ortaya atılan kullanma zimmeti, gerçek bir zimmete geçirme eylemi olarak kabul görmemiştir ${ }^{25}$. Hatta kullanma zimmetinin geçici ve istisnai niteliği olan failin malik olma gibi bir isteğinin bulunmaması, suçun zimmet olarak algılanmasını engellemiştir ${ }^{26}$. Yine bu dönemdeki bir görüșe göre failin, görevi nedeniyle kendisine devredilen otomobil, bilgisayar gibi kullanmakla tükenmeyen eşyaları kullanması halinde, eylemi sadece disiplin suçu ve görevi kötüye kullanma suçuna sebebiyet verecekti ${ }^{27}$.

Yargitay, kullanma zimmetini temel zimmetin bir şekli olarak kabul etmiş, "faydalanma kastı" ve "temellük kastı" şeklinde ayrım yaparak suçu belirlemeye çalışmıştır. ${ }^{28}$ Buna rağmen Yargıtay'ın benzer olaylar için verdiği kararlarda, görevi kötüye kullanma suçundan hüküm kurduğu haller de görülmüştür ${ }^{29}$.

lara tekrar yatıran ve bunu fark edilmeden 8.12.1997 tarihine kadar sürdüren sanığın bu eyleminin kullanma zimmeti niteliğinde olduğu, bu tarihte amir N.S.'nin durumu öğrenerek araştırmaya ve sanıktan sorup uhdesinde bulunan paraları yatırmaya başlamasıly eyleminin temellük zimmetine dönüştüğü gözetilip, kullanma zimmeti olarak kabul edilen dilimde sanığın çekip kullandıktan sonra yatırdığı paralardan sağladığı nema miktarına 8.12.1997 tarihinden sonra uhdesinde bulunan para tutarı eklenerek zimmet suçundaki ağır para cezasının belirlenmesi gerekirken eylemlerinin tümünün kullanma zimmeti olarak kabulü ile yazılı şekilde ağır para cezasına hükmolunması", Yargıtay 5. CD, 21.6.2001 tarih ve E. 2000/7967 K. 2001/4427 sayılı kararı, <http://www.kazanci.com/kho2/ibb/giris.html> Erişim Tarihi 23 Temmuz 2020.

24 Özgenç, Zimmet, s. 25; Süheyl Donay, “Türk Hukukunda Zimmet”, 1968, 2(3), İstanbul Üniversitesi Mukayeseli Hukuk Araştırmaları Dergisi, s. 46, <https://dergipark.org.tr/tr/pub/ iumhad/issue/1282/15101> Erişim Tarihi 10 Mart 2020.

25 Faruk Erem, "Zimmet ve İhtilas", 1957, 14(1), Ankara Üniversitesi Hukuk Fakültesi Dergisi, s. 42, < https://dergipark.org.tr/tr/pub/auhfd/issue/42819/517618> Erişim Tarihi 13 Mart 2020.

26 Toroslu, s. 284.

27 Erem, s. 42; Toroslu, s. 284; Özgenç, Zimmet, s.25; Halid Özkan, Türk Ceza Kanunu'nda Zimmet Suçu, 1. Baskı, Adalet Yayınevi, 2013, s. 97.

28 "Görüldüğü üzere sanık, idarenin hiçbir resmi yazısı, tespiti ve ihtarı olmadan eylem idarece tespit edilmeden önce, aldığı paraları yatırmıştır. Sanığın amacı idareye ait parayı temellük etmek olmayıp, bu parayı kullanmak ve bu yolla kendisine çıkar sağlamaktır. Paranın 10 ve 23 gün gibi kısa sürelerle kullanılarak nemasından yararlanıldıktan sonra hiçbir uyarı olmadan iade edilmesi biçimindeki oluşan eylem, "kullanma zimmeti" suçunu oluşturmaktadır", YCGK, 27.05.1991 tarih ve E. 1991/135, K. 1991/170 say1lı kararı, <http://www. kazanci.com/kho2/ibb/giris.html> Erişim Tarihi 25 Nisan 2020.

29 "Dosya içeriğine göre, sanık borç alarak verdiği 1.500.000 TL kooperatif parasına karşılık 
Doktrin ve uygulamadaki kullanma zimmetinin cezalandırılabileceğine ilişkin tereddütlere rağmen, kanaatimizce 765 sayılı TCK' daki zimmet suçuna ilişkin düzenleme de kullanma zimmetinin cezalandırılması bakımından yeterliydi. 765 say1lı TCK'da zimmet suçu m. 202/1'de, "görevi sebebiyle kendisine tevdi olunan veya muhafaza, denetim veya sorumluluğu altında bulunan para veya para yerine geçen evrak veya senetleri veya diğer mallar zimmetine geçiren memura alt yıldan oniki ylla kadar ağı hapis ve meydana gelen zararın bir misli kadar ağır para cezası verilir ” şeklinde düzenlenmişti. Maddede, malın geçici bir süre kullanılmasının da zimmet suçunun bir türünü oluşturacağ alındığında kullanma zimmeti fiillerini de kapsadığ 1 kabul edilmelidir. Buna rağmen söz konusu dönemde kullanma zimmetinin cezalandırılmasına ilişkin tereddütler olmasından dolayı kanun koyucu 5237 sayılı TCK'da kullanma zimmetine ilişkin özel bir düzenlemeye yer vererek, önceki dönemde oluşan tereddütlere son vermiştir. Bu düzenlemeyle söz konusu fiillerden dolay1 failin cezalandırılabilmesi konusunda bir şüphe kalmamıştır.

\section{5237 Sayılı TCK'da Kullanma Zimmeti}

Kullanma zimmeti kamu görevlisinin, görevi sebebiyle zilyetliği kendisine bırakılmış veya koruma ve gözetimiyle sorumlu olduğu malı, iade etmek üzere ve mal edinme amacı gütmeden geçici bir süre için kullanmak üzere zimmetine geçirmesidir. Suç konusu mal üzerinde malikin bulunabileceği tasarruflarla zimmet suçu ortaya çıktığına göre, kullanmanın da malikin gerçekleştirebileceği bir tasarruf kapsamında olup olmadığının belirlenmesi gerekir. Malikin bulunabileceği bir kullanım, kullanma zimmeti kabul edilecektir. Bu kapsamın dışında kalan hallerde, kullanma zimmeti oluşmayacaktır. Öte yandan malın tahsisi kapsamındaki kullanımlar, bunlara izin veren özel düzenlemeler bulunmasa bile kullanma zimmeti say1lmazlar ${ }^{30}$.

çek alarak yevmiye defterinin emanetler hesabı borcuna ve bankalar hesabı alacağına işlemiştir. Sanık tarafından söz konusu çek inşaat malzemeleri satan bir ticari işletmeye ciro edilerek borç para alınmış ve bu firmadan 31.10.1987 tarihinde 1.066.500 liranın, 30.10.1987 günü ise borç para verilen Yaşar'dan 466.500 liranın tahsil edildiği yevmiye defterine kaydedilmiştir. Defteri Kebirin 31.8.1987 tarihli sayfasında 1.500.000 liranın gider olarak gösterildiği, 31.10.1987 günü ise aynı miktarın gelir olarak hesaba aktarıldığı saptanmıştır. Görüldüğü üzere borç verilen kooperatif parası kayıtlara işlenmiş olup sanığın temellük etme kast1 yoktur. Bu nedenle zimmet oluşmamıştır", YCGK, 25.06.1990 tarih ve E. 1990/5-174, K. 1990/193 sayılı kararı, <http://www.kazanci.com/kho2/ibb/giris.html> Erişim Tarihi 13 Aralık 2020.

30 Okuyucu Ergün, s. 118; Centel, s. 2794. 
Kullanma zimmeti, malın geçici bir süre için kullanıldıktan sonra iade edilmek üzere alındığı anda tamamlanır. Failin, malı iade etme imkân ve iktidarına sahip olmasının suçun oluşması üzerinde bir etkisi yoktur ${ }^{31}$. Ancak mal halihazırda görevi sebebiyle kamu görevlisinin fiili hâkimiyetinde olduğundan, malın failin veya üçüncü bir kişinin yarar elde edebileceği bir egemenlik alanına sokulması gerekir. Dolayısıyla görevi sebebiyle kurum içerisinde tahsil etmiş olduğu paraları kendi hususi harcaması için kullanıp, daha sonra iade etmek üzere alan kamu personelinin, paralarla beraber henüz kurumdan çıkmadan yakalanması kullanma zimmetine teşebbüs olarak kabul edilmelidir ${ }^{32}$.

Suç çoğunlukla tüketilebilir veya harcanabilir nitelikteki para gibi misli mallar üzerinde gerçekleştirilmesine rağmen; misli ya da misli olmayan herhangi bir mal üzerinde de suç işlenebilir. Örneğin, görevi sebebiyle zilyetliği kendisine devredilmiş olan belediyeye ait kamyonu mesai saatleri dışında kiralayarak para elde eden kamu görevlisinin fiili, misli olmayan bir malda gerçekleştirilen kullanma zimmeti olarak değerlendirilmelidir. Suçun konusu, kullanma suretiyle zimmete geçirilen malın kendisi olmayıp failin bundan elde ettiği nemadır (yarar). Nema, failin kendisi veya üçüncü bir kişi için elde edilebilir. Malın, devlet veya başka bir kamu kurumu için kullanılmış olmas1 durumunda kullanma zimmetinden değil; görevi kötüye kullanma suçundan bahsedilmesi gerekir ${ }^{33}$.

Öte yandan kullanılan malın, para veya para yerine geçen evrak veya senet gibi şeyler olması durumunda malın kullanılması açısından sürenin önemi yoksa da bu sürenin maldan bir nema elde edilebilecek kadar makul bir süreye karşılık gelmesi gerekir ${ }^{34}$. Örneğin, evine ait kirayı üzerindeki kamu idaresine ait paradan ödeyen şahsın, daha sonra kısa bir sürede bankadan para çekip bu eksiği tamamlaması durumunda, kişinin bu fiili dolayısıyla bir nemadan

31 Şenel Sarsıkoğlu, "Zimmet Suçunun Kooperatifler Kanunu ve Yardım Toplama Kanunu Özelinde Değerlendirilmesi, 2013, (104), Türkiye Barolar Birliği Dergisi, s. 212, < http:// tbbdergisi.barobirlik.org.tr/m2013-104-1248> Erişim Tarihi 17 Aralık 2020.

32 Aynı yönde bkz. Handan Yokuş Sevük, Türk Ceza Hukuku Özel Hükümler, 2. Baskı, Adalet Yayınevi, 2019, s. 607; Malın kullanılmasına başlanmadan önceki evrede halihazırda failin tasarruf alanında olmasından dolayı ancak hazırlık hareketlerinden söz edilebileceği ve bu yüzden kullanma zimmetine teşebbüsün mümkün olmayacağına ilişsin görüş için bkz. Zeki Hafızoğulları ve Ezgi Aygün Eşitli, Kamu İdaresinin Güvenilirliğine Karşı Suçlar, 1. Baskı, US-A Yayınc1lik, 2014, s.22.

33 Artuk ve Gökcen, s. 1029.

34 Akçin, s. 225.

474 Ankara Hacı Bayram Veli Üniversitesi Hukuk Fakültesi Dergisi C. XXV, Y. 2021, Sa. 2 
istifade ettiğini söylememiz mümkün değildir. Örnekteki gibi kullanımlar daha sonra malın değerinin azlığı kısmında tartışacağımız kullanma zimmeti açısından müsamaha edilen zimmet kavramı üzerinden tartışılabilir.

\section{Kullanma Zimmetinin Hukuki Niteliği}

Kullanma zimmeti hukukumuzda, ilk defa 5237 sayılı TCK m. 247/3'te açıkça kanuni zemine kavuşmuştur. Düzenlemenin niteliği öğretide tartı̧̧malıdır. Bağımsız bir suç tipi olduğunu kabul eden yazarlar olduğu gibi ${ }^{35}$, zimmetin daha az cezayı gerektiren bir nitelikli hali olduğunu kabul eden yazarlar ${ }^{36}$ da bulunmaktadır.

Kullanma zimmetini, bağımsız bir suç tipi olarak kabul eden yazarlardan bazılarına göre kullanma zimmeti, maddi ve manevi unsurdaki farkl1liklardan dolayı zimmetin özel bir şekli olarak kabul edilmelidir ${ }^{37}$. Yine bu suçu bağımsız bir suç tipi olarak kabul eden diğer bazı yazarlara göre ise failin malı kullanıp iade etmek üzere alması, malın tamamen gerçek amacı dışına çıkartılması şeklinde kabul edilemeyeceğinden, gerçek bir zimmete geçirme değildir ${ }^{38}$. Failin bu amaçla alması, suçun temel zimmet suçu kapsamında kabul edilmesini engelleyen özel bir unsur olarak değerlendirilmektedir ${ }^{39}$.

Kullanma zimmetini, suçun daha az cezayı gerektiren bir nitelikli hali olarak kabul eden yazarlardan bazılarına göre ise kullanma zimmeti, zimmet suçunun temel şekli ile aynı maddi unsurlara sahiptir ve kullanma zimmetinin özellikle sonucu, suçun nitelikli bir hal olarak kabul edilmesini gerektirmektedir ${ }^{40}$. Bu görüşe göre, kullanma zimmetinin daha az cezay1 gerektiren bir nitelikli hal olması, malın geçici olarak kullanıldıktan sonra iade edilmek üzere alınması nedeniyledir ${ }^{41}$. Öyle ki bu durum, failin tehlikeliliğini

35 Bkz. Hafizoğulları ve Aygün Eşitli, s. 21; Zeki Hafizoğulları ve Muharrem Özen, Türk Ceza Hukuku Özel Hükümler- Millete ve Devlete Karşı Suçlar, 1. Baskı US-A Yayıncılık, 2016, s.15.

36 Veli Özer Özbek, Koray Doğan ve Pınar Bacaksız, Türk Ceza Hukuku Özel Hükümler, 15. Bask1, Seçkin Yayınc1lık, 2020, s. 1059; Centel, s. 2794; Özkan, s.91.

37 Hafızoğulları ve Aygün Eşitli, s. 21.

38 Bkz. Okuyucu Ergün, s. 123.

39 Bkz. Okuyucu Ergün, s. 123.

40 Antonio Segreto ve Gaetano De Luca, Delitti Dei Pubblici Ufficiali, SEGRETO, Antonio/ DE LUCA, Gaetano, Delitti dei pubblici ufficiali, 1999, s. 127'den naklen Okuyucu Ergün, s. 123.

41 Okuyucu Ergün, s.123. 
ve oluşturduğu zararı azalttığından daha az ceza vermeyi gerektiren haklı bir durumu ortaya çıkarmaktadır ${ }^{42}$.

Bu doğrultuda biz de TCK m. 247/3'te yer alan kullanma zimmeti düzenlemesinin, zimmetin daha az cezay1 gerektiren bir nitelikli hali olduğunu düşünüyoruz. Nitelikli haller, suçun temel halinde bulunmas1 zorunlu olan kurucu unsurlara eklenen, buna rağmen suçun hukuki varlığına zarar vermeyen ve hukuki vasfinı değiştirerek başka bir suça dönüşmesine neden olmayan sebeplerdir ${ }^{43}$. Bir başka ifadeyle suçun temel şekline eklenirler ve suçun haksızlık içeriğine etki ederek, failin daha fazla veya daha az cezalandırılmasını sağlarlar ${ }^{44}$. Bu itibarla kullanma zimmeti, zimmet suçunun temel şekline ait tüm unsurlara sahiptir. Ancak fiilin gerçekleştirildiği sırada güdülen amaç ve suçun konusu gibi unsurlar yönünden zimmet suçunun daha az haksızlık meydana getiren bir şeklidir. Bu niteliğiyle kullanma zimmetinin, zimmet suçunun daha az cezayı gerektiren bir nitelikli hali olduğunun kabulü gerekir. TCK'daki kullanma zimmetinin düzenlenme şekli ve gerekçesi de bu görüşü destekler niteliktedir. Zira maddede kullanma zimmeti, "zimmet suçunun, malın geçici bir süre kullanıldıktan sonra iade edilmek üzere işlenmesi" şeklinde düzenlenmiş, cezanın belirlenmesinde zimmet suçunun temel şeklinin cezası dikkate alınmıştır. Gerekçede ise nitelikli hal durumunu destekleyecek şekilde; "maddenin son fikrasında, kullanma zimmetine ilişkin hükme yer verilmiştir. Bu hükümde, zimmet suçunun, malın geçici bir süre kullanıldıktan sonra iade edilmek üzere işlenmesi hâlinde, verilecek cezada indirim yapılması öngörülmüştür" ifadesine yer verilmiştir. Görülüyor ki kanun koyucu gerekçede kullanma zimmetini, faile daha az ceza verilmesini gerektiren bir nitelikli hal olarak kabul etmektedir.

\section{Kullanma Zimmetinin Unsurları}

\section{A. Malın İade Edilmek Üzere Alınması}

Kullanma zimmetinde, fail zimmet suçunun temel şeklinde olduğu gibi malikin bulunduğu tasarruflarda bulunmakta; ancak bununla birlikte failde iade

42 Okuyucu Ergün, s.123.

43 Sulhi Dönmezer ve Sahir Erman, Nazari ve Tatbiki Ceza Hukuku Genel Kısım Cilt: II, 12. Bası, Beta Basım Yayım, 1999, s.339; Hakan Hakeri, Ceza Hukuku Genel Hükümler, 22. Bask1, Adalet Yayınevi, 2019, s. 141.

44 Koca ve Üzülmez, Genel Hükümler, s. 139; Nitelikli hallerin, kusurluluğun veya hukuka aykırılığın yoğunluğunda değişiklik meydana getirdiği yönündeki görüş için bkz. Hakeri, s. 142. 
etme amacı bulunduğundan, zimmet eylemi geçici bir nitelikte kalmaktadır ${ }^{45}$. Faildeki iade etme amac1, mal alınmadan önce bulunmalı, bütün kullanma süresince ise devam etmelidir ${ }^{46}$. İspatı failin iç dünyasındaki bir hususa ilişkin olmakla birlikte; baştan itibaren iade etme amacı olmadan, sadece şikâyet ya da soruşturma sonrasında malın iade edilmesi durumunda fiil kullanma zimmeti değil, zimmet suçunun temel şekli kapsamında değerlendirilmelidir ${ }^{47}$. Yine failin kullanıp iade etmek üzere aldığı mal üzerinde sonradan mal edinme kastı ortaya çıkarsa fiil, zimmet suçunun temel şekline dönüşecektir.

Failin malı iade etme amacıyla almış olmasının kullanma zimmeti açısından yeterli olduğunu belirtmek gerekir ${ }^{48}$. Kanundaki düzenlemeyi değerlendirdiğimizde de iadenin yapılmış olmasının aranmadığını söyleyebiliriz. Dolayısıyla kullanılıp iade edilmek üzere alınan malın, iadesi gerçekleşmemişse bile kullanma zimmeti oluşur. Böyle bir durumda iade failin cezasında etkin pişmanlık hükümleri uyarınca indirim noktasında dikkate alınmalıdır. Kanaatimizce her ne kadar kanuni düzenlemede suçun olası kastla işlenebilmesine engel bir durum söz konusu olmasa da suçun oluşması bakımından iade aranmadığı için somut olaylarda kullanma zimmetinin olası kastla işlenmesi mümkün gözükmemektedir. Örneğin ertesi gün kendisine bir yerden gelecek paraya güvenerek zilyetliğindeki para ile kira borcunu ödeyen fakat beklediği para gelmediği için iadeyi gerçekleştiremeyen failin hareketi, kullanma zimmeti kapsamında değerlendirilmelidir.

Kanundaki düzenlemeye rağmen öğretide 765 sayılı mülga TCK döneminde uygulanan ve günümüzde de süren kullanma zimmetine ilişkin Yargıtay uygulamasını ${ }^{49}$ esas alarak iadenin de gerçekleşmiş olmasını arayan

45 Özbek, Doğan ve Bacaksız, s. 1059.

46 Centel, s. 2794.

47 Okuyucu Ergün, s. 119.

48 Aynı yönde bkz. Centel, s. 2795.

49 "Sanıkların suç tarihlerindeki görev, yetki ve sorumluluklarının kooperatiften ve tescil edildiği Ticaret Sicil memurluğundan sorulmadan noksan soruşturma sonucu yazılı şekilde hüküm kurulması, Sanıkların kooperatife ait toplam 460.000.000 lirayı hissedarı oldukları B. İnşaat Ltd. Şirketi'ne 8 ay kadar kullandırdıktan sonra herhangi bir ihbar veya sonuçlandırma yapılmadan tekrar kooperatif hesaplarına aktardıkları anlaşılmakla eylemlerinin kullanma zimmeti niteliğinde bulunduğu", Yargitay 5. CD, 25.02.2004 tarih ve E. 2002/ 5686 K. 2004/ 1177 sayılı kararı, <http://www.kazanci.com/kho2/ibb/giris.html> Erişim Tarihi 13 Aralık 2020.

“5237 Sayılı TCK’nın 247. Maddesinde düzenlenen zimmet suçunun oluşması için "kamu görevlisinin veya özel mevzuatları gereği kamu görevlisi gibi cezalandırılabilen kişile- 
yazarlar bulunmaktadır ${ }^{50}$.

Yargitay, söz konusu dönemde temel zimmet ve kullanma zimmeti suçlarını ayırt etmek için iadenin yapıldığı zamanı esas almaktaydı. Buna göre, failin herhangi bir uyarı, ihbar, şikâyet, denetim veya soruşturma olmaksızın, malın iadesini yapmış olması halinde eylemi kullanma zimmeti olarak değerlendiriliyordu ${ }^{51}$. Malın fail tarafindan şikâyet ya da soruşturma sonrasında iade edilmesi halinde ise temellük kastıyla hareket ettiği kabul edilmekte ve böyle bir durumda fiil, zimmet olarak değerlendirilmekteydi 52. Kastın belirlenmesi açısından iadenin yapıldığı zaman aralığının dikkate alındığ 1 bu uygulama, suçun manevi unsurunu görmezden geldiği gerekçesiyle eleştirilmiştir ${ }^{53}$.

rin görevi nedeniyle zilyetliği kendisine devredilmiş olan veya koruma ve gözetimiyle yükümlü olduğu malı kendisinin veya başkasının yararına zimmetine geçirmesinin" gerektiği, öte yandan eylemin kullanma zimmeti olarak kabul edilebilmesi için, failin görevi gereği yasal olarak kendisine tevdii edilen parayı belli bir süre kullanıp hakkında herhangi bir uyarı, ihbar, şikayet, denetim veya soruşturma olmaksızın kendiliğinden yatırması gerektiği, denetim ve şikayet sonrası ortaya çıkan bu fiillerin dairemizin yerleşik uygulamalarına göre mal edinme kastına bağlı olarak bir bütün halinde temellük zimmeti vasfinda olarak kabul edildiği”, Yargitay 5.CD, 10.10.2018 tarih ve E. 2014/11541, K. 2018/7128 sayılı kararı, $<$ https://karararama.yargitay.gov.tr/> Erişim Tarihi 14 Haziran 2020.

50 Hafızoğulları ve Özen, s.16; Özbek, Doğan ve Bacaksız, s. 1060.

51 "Emlak Bankası Kırşehir Şube Müdürlüğünde yetkili gişe memuru olarak görev yapan sanığın, bir kısım mudilerin bilgisi dahilinde ve bir kısmının haberi olmaksızın onların vadesiz hesaplarındaki paraları sahte tediye fişleri düzenleyerek çekip kullandıktan sonra bir uyarı ve soruşturma olmadan bunları yatırması eylemlerinin kullanma zimmeti ve olayın soruşturmaya başlanması ile sanıktan sorulup uhdesinde bulunan paraları iade etmesi șeklindeki eylemlerinin ise temellük zimmeti niteliğinde olduğu gözetilip", Yargıtay 5. CD, 27.1.2004 tarih ve E. 2002/8074, K. 2004/373 say1lı karar1, <http://www.kazanci. com/kho2/ibb/giris.html> Erişim Tarihi 13 Aralık 2020); Yargıtay'ın söz konusu uygulaması kanaatimizce kullanma zimmetinde etkin pişmanlık hükümlerinin uygulanmasını son derece kısıtlamaktadır. Zira kullanma zimmeti suçunun kabulü için malın herhangi bir şikâyet, soruşturma vb. olmadan iadesinin yapılmış olması arandığından, kullanmak üzere aldığı malı soruşturma evresinde iade eden failin fiili temel zimmet kabul edilecek, kovuşturma öncesi iadeye ilişkin etkin pişmanlık hükümlerini düzenleyen m. 248/2'nin kullanma zimmeti bakımından uygulanması imkânsız hale gelecektir. Ancak kullanma zimmeti bakımından soruşturma öncesi etkin pişmanlığ düzenleyen m. 248/1'in uygulanması mümkündür.

52 "Kasada paranın bulunmadığını belirlemesi ve durumu belediye bildirmeye hazırlandığ sırada sanığın 30.04.1999 tarihi itibariyle zimmetine geçirdiği bu tutarı belediye hesaplarına yatırdığının anlaşılması karşısında, sanığın bu eyleminin kullanma zimmeti niteliğinde değil, yapılan uyarı ve durumun araştırılmaya başlanması üzerine zimmete geçirilen bedelin ödenmesi nedeniyle basit ve temellük zimmeti niteliğinde olduğu", Yargitay 5. CD, 20.04.2000 tarih ve E. 2000/729, K. 2000/1338 sayıl1 kararı, <http://www.kazanci.com/ kho2/ibb/giris.html > Erişim Tarihi 13 Aralık 2020.

53 Bkz. Akçin, s.225; Hasan Tahsin Gökcan, Görevi Kötüye Kullanma, Zimmet, Banka 
Kanaatimizce de her ne kadar bir gösterge olsa da failin kastının, iadenin yapıldığ1 zamana göre belirlenmesi ceza adaletiyle bağdaşmaz. Bu bağlamda örneğin sırf geçici bir süre kullanıp iade etmek üzere alınan bir malın, alındığ 1 tarihin ertesi günü gerçekleştirilen denetimde ortaya çıkmasından dolayı faile zimmet suçunun temel şeklinden ceza verilmesi kabul edilemez. Bunun karşısında mal edinmek amacı olmasına rağmen zimmete geçirmenin hemen akabinde durumun tespit edilmesi nedeniyle failin kullanma zimmetinden sorumlu tutulması da doğru değildir.

Failin kastını belirlemek için her somut olayın kendi içinde değerlendirilmesi yerine, iadenin yapılmasının dikkate alındığ 1 bir uygulama kişiler bakımından mağduriyete sebebiyet vermektedir ${ }^{54}$. Yalnızca malın iade edilmemiş olmasından dolayı zimmet suçunun temel şeklinin oluştuğunun kabulü hatalıdır. Kanaatimizce malın geçici bir süre için kullanılıp iade edilmek üzere alındığ 1 durumlarda kullanma zimmetinin; failin eyleminin mal edinme olduğu durumlarda zimmet suçunun temel şeklinin oluştuğunun kabul edilmesi gerekir ${ }^{55}$. Öyle ki failin kastının belirlenmesinde tereddüde düşüldüğü hallerde artık hâkimin, "şüpheden sanık yararlanır" şeklindeki ilke doğrultusunda, kullanma zimmetinden ceza vermesi daha doğru olur ${ }^{56}$.

\section{B. Zimmete Geçirilen Malın Geçici Bir Süre İçin Kullanımı}

Kullanma zimmetini, zimmet suçunun temel şeklinden ayıran önemli unsurlardan bir diğeri, malın geçici bir süre kullanımı için alınmasıdır. Kullanım süresi kısa olabileceği gibi uzun da olabilir. Hatta kullanım anlık da gerçekleşebilir. Yargıtay'ın verdiği kararlarda da geçiciliğin belirlenmesi için belirli süre sınırı çizilmemiştir. Kararlarda, geçici süre olarak 1 ila 21 günün kabul edildiği somut olaylar olduğu gibi, 73 ila 209 günün kabul

Zimmeti, İrtikap, Rüşvet Suçları ve Kamu İdaresine Karşı İşlenen Suçlar, 1. Baskı, Seçkin Yayınc1lik, 2018, s. 337.

54 “Öte yandan eylemin kullanma zimmeti olarak kabul edilebilmesi için, failin görevi gereği yasal olarak kendisine tevdii edilen parayı belli bir süre kullanıp hakkında herhangi bir uyarı, ihbar, şikayet, denetim veya soruşturma olmaksızın kendiliğinden yatırması gerektiği, denetim ve şikayet sonrası ortaya çıkan bu fiillerin dairemizin yerleşik uygulamalarına göre mal edinme kastına bağlı olarak bir bütün halinde temellük zimmeti vasfinda olarak kabul edildiği”, Yargitay 5.CD, 10.10.2018 tarih ve E. 2014/11541, K. 2018/7128 sayılı kararı, $<$ https://karararama.yargitay.gov.tr/> Erişim Tarihi 15 Haziran 2020.

55 Aynı yönde bkz. Mustafa Özen, Öğreti ve Uygulama Işı̆̆ında Ceza Hukuku Özel Hükümler, 3. Bask1, Adalet Yayınevi, 2019, s. 972; Gökcan, s. 337.

56 Aynı yönde bkz. Akçin, s.226. 
edilerek kullanma zimmetinden ceza verildiği haller görülmektedir ${ }^{57}$. Ancak çok uzun süreli kullanımlar ve malın bu uzun süreye rağmen iade edilmediği hallerde artık failin kastının kullanma olmayıp mal edinme olduğunun yorumu yapilabilir ${ }^{58}$.

Geçicilikten, kullanımın sadece belirli bir süre için olmas1 anlaşılmamalıdır. Geçici bir kullanımın kabul edilebilmesi için malın alındığ 1 takdirde idare ve tahsis edildiği hizmet bakımından yarattı̆̆1 etki de dikkate alınmalıdır. Malın kullanılış şekli, tahsis amacını değiştiriyor, kullanılan malı, tahsis edildiği kamu hizmetinin yürütülmesi bakımından tamamen ya da büyük oranda iş görmez bir hale getiriyorsa, artık bu durumda zimmet suçunun temel şeklinden bahsetmek gerekir ${ }^{59}$. Böyle bir kullanım, geçici olarak kabul edilemez.

\section{VII.Nitelikli Kullanma Zimmeti}

Türk Ceza Kanunu m. 247/1'de zimmet suçunun temel şekline; m. 247/2'de ise zimmetin açığa çıkmamasına yönelik hileli davranışların yapılmasını cezalandıran nitelikli haline yer verilmiştir. Kullanma zimmetinin, zimmet suçunun temel ve daha ağır cezayı gerektiren nitelikli halinden sonra, m. 247/3'te düzenlenmiş olması nedeniyle kullanma zimmetinin de nitelikli

57 "Sosyal Güvenlik Kurumu Başkanlığında başmüfettiş olarak görev yapan sanık S.S'nin, 2009 yılı Nisan, Temmuz, Eylül, Ekim, Kasım, Aralık ve 2010 yılı Ocak aylarında aldığ harcırah avanslarından yaptığı harcamalar düşüldükten sonra kalan miktarları Rehberlik ve Teftiş Başkanlığı Yönetmeliğinin 92. maddesi uyarınca ilgili ayın son günü iade etmesi gerekirken, Nisan 2009 tarihinde 1.144, 05 avans artığını 209 gün, Temmuz 2009'da 690,20 TL avans artığını 159 gün, Eylül 2009'daki 2.175,50 avans artığını 98 gün, Ekim 2009'daki 1.688,77 TL avans artığını 83 gün, Kasım 2009'da 210,27 TL avans artığını 60 gün, Aralık 2009'daki 1.821,55 TL avans artığını 74 gün, Ocak 2010'daki 1.412,06 TL avans artığını 73 gün üzerinde tuttuktan sonra kurumun hesabına yatırması şeklindeki gerçekleştiği anlaşılan eylemlerinin zincirleme kullanma zimmeti suçunu oluşturduğu nazara alınarak", Yargıtay 5. CD, 19.01.2015 tarih ve E. 2015/7176 K. 2015/1094 sayıl1 kararı, <http://www.kazanci. com/kho2/ibb/giris.html> Erişim Tarihi 9 Ağustos.2020.

"Sanığın görevi gereği yasal olarak kendisine tevdii edilen malı belli bir süre kullanıp hakkında herhangi bir uyarı, ihbar, şikâyet veya soruşturma olmaksızın kendiliğinden kuruma yatırması halinde kullanma zimmetinin oluşacağı gözetildiğinde sanığın 1 ila 21 gün arasinda uhdesinde tutup denetim öncesinde yatırdığ $6.687 \mathrm{TL}$ ve 1.006,50 TL olmak üzere toplam 7.693,50 TL'ye yönelik eyleminin kullanma zimmeti”, Yargıtay 5. CD, 28.04.2016 tarih ve E. 2014/ 3800 K. 2016/ 4356 say1l kararı, <http://www.kazanci.com/kho2/ibb/giris. html $>$ Erişim Tarihi 9 Ağustos 2020.

58 Özbek, Doğan ve Bacaksız, s. 1060.

59 Necati Meran, Zimmet- Rüşvet- İrtikap ve Görevi Kötüye Kullanma Suçları, 1. Baskı, Seçkin Yayıncılık, 2008, s. 42; Cengiz Kütük, Türk Ceza Hukukunda Zimmet Suçu, 1 Bask1, Seçkin Yayınc1lık, 2016, s. 144. 
olarak işlenebileceği kabul edilmektedir ${ }^{60}$.

Zimmet suçunun daha ağır cezalandırılmasını gerektiren nitelikli haline ilişkin ikinci fikrasında, zimmet olgusunun sonradan anlaşılmasının önüne geçmeye yönelik her türlü hilenin nitelikli hali oluşturacağı düzenlenmiştir. 765 sayılı TCK m. 202/2'de ise nitelikli halin varlığının kabul edilebilmesi için hilenin "dairesini aldatacak" düzeyde olması gerekliydi" ${ }^{61}$ Hile, suçun ortaya çıkmasını engellemek amacıyla gerçekleştirilen her türlü yanıltıcı harekettir $^{62}$. Burada söz konusu hileye, kamu görevlisi hukuka uygun bir şekilde zilyet olduğu mal üzerinde gerçekleştirdiği zimmet olgusunun ortaya çıkmasını engellemek amacıyla başvurmaktadır ${ }^{63}{ }^{64}$. Çünkü esasen mal zaten hâlihazırda failin egemenlik alanında bulunmaktadır. ${ }^{65}$ Hileli davranışların kabulü için muhatap alınan kişi ya da kişilerin gerçekten aldatılmış olması gerekmemektedir $^{66}$. Hareketin, aldatıc1 olmas1 yeterlidir ${ }^{67}$. Ancak öte yandan Yargıtay, nitelikli halin kabulü için hileli davranışların kurum içi basit bir

${ }^{60}$ Erdal Baytemir, Açıklamal1- İçtihatlı Kamu İdaresinin Güvenilirliğine ve İşleyişine Karşı Suçlar ile Banka Zimmeti, 1. Bask1, Adalet Yayınevi, 2011, s. 59.

${ }^{61}$ Koca ve Üzülmez, Özel Hükümler, s. 982.

62 Koca ve Üzülmez, Özel Hükümler, s. 981.

63 Koca ve Üzülmez, Özel Hükümler, s. 983; Sarsıkoğlu, s. 213.

64 "Oluşa ve dosya içeriğine göre de, sözlü olarak maaş bordrolarını hazırlamak üzere tahakkuk memuru olarak görevlendirilip bu görevi itiraz etmeksizin yürüten sanığın, maaş bordrolarının tahakkukunu doğru olarak düzenleyip İmar ve Fen İşleri Müdürlüklerine ait personelin özel hizmet tazminat tutarlarını icmal bordrosuna fazla olarak geçirip buna bağlı olarak düzenlenen verilen emirleri ile fazla olan miktarların bankada kendi hesabına yatırılmasını sağladığı sabit ise de; zimmet suçunun oluşabilmesi için paraların kendisine görevinin normal fonksiyonu icabı ve kanuna uygun olarak tevdiinin zorunlu olduğu, kendisine usulsüz olarak ödeme yapılmasına olanak sağlayan belgeler düzenleyerek kullanmak suretiyle çıkar sağlama eylemlerinin belgelerin aldatıcı nitelikte olması durumunda evrakta sahtekarlık ve kamu kurumuna karşı dolandırıcılık, aldatıcılığın bulunmaması durumunda da kamu kurumuna karşı dolandırıcılık ve görevi kötüye kullanma suçlarını oluşturacağ 1 gözetilmeksizin suç vasfinda yanılgıya düşülerek yazılı şekilde zimmet suçundan hüküm kurulması", Yargitay 5. CD, 01.11.2011 tarih ve E. 2007/5928 K. 2011/23185 say1l karar1, <http://www.kazanci.com/kho2/ibb/giris.html> Erişim Tarihi 13 Aralık 2020.

${ }_{65}$ Artuk ve Gökcen, s. 1019.

66 Özgenç, Zimmet, s. 34.

67 Özgenç, Zimmet, s. 34.

Ankara Hacı Bayram Veli Üniversitesi Hukuk Fakültesi Dergisi C. XXV, Y. 2021, Sa. 2481 
incelemeyle anlaşılamayacak boyutta olmasını $\operatorname{aramaktad}^{68}{ }^{68},{ }^{69}$.

\section{Malın Değerinin Azlığı}

Türk Ceza Kanunu m. 249'a göre, zimmet suçunun konusunu oluşturan malın değerinin azlığı nedeniyle verilecek ceza üçte birden yarıya kadar indirilir. Zimmet suçunun temel şekli bakımından malın değerinin azlığ belirlenirken, malın suçun işlendiği tarihteki değeri dikkate alınmalıdır ${ }^{70}$. $\mathrm{Bu}$ değerin hesaplanmasında ayrıca idarenin uğramış olduğu zarar, yoksun kaldığı gelirler veya gecikme zammı-faiz gibi kalemler ilave edilmez ${ }^{71}$. Ancak bu noktada kullanma zimmeti, zimmet suçunun temel şeklinden ayrılmaktadır. Kullanma zimmetinde daha önce belirttiğimiz gibi suçun konusu, failin maldan elde etmiş olduğu nemadır. Bu sebeple malın değerinin azlığı dikkate alınırken, kullanma zimmetine konu malın değeri değil; elde edilen nema göz önüne alınacaktır ${ }^{72}$.

68 “6.02.2007 ile 23.06.2009 tarihleri arasında 165 defada toplam 63.487'yi kendi kredi kartından çektiği, S...S..'nin aynı şekilde 27.02.2007 ile 16.07. 2009 tarihleri arasında 50 defada toplam 30.493 TL'yi kendi kredi kartından çektiği, bu şekilde hileli davranışlarla gerçekleştirilen eylemlerinin kurum için kaba bir inceleme ile ortaya çıkarılmasının mümkün olmadığı, ancak suç tarihlerinde kredi kartlarından İSKİ adına yapılan tahsilat dökümlerinin istenmesi üzerine ilgili bankalar tarafından gönderilen yazı cevapları ekindeki hesap dökümlerinin incelenmesi sonucunda yani daire dışı bilgi ve araştırmayla saptanabilmesi karşısında zincirleme nitelikli kullanma zimmeti suçlarını oluşturduğu nazara alınarak her bir aboneden nakit tahsilat tarihi ile bu abonelerin yatırmış oldukların bedelin", Yargıtay 5. CD, 27.10.2014 tarih ve E. 2013/6222 K. 2014/10114 say1lı kararı, <http://www.kazanci.com/ kho2/ibb/giris.html> Erişim Tarihi 1 Eylül 2020.

69 "Vergi Dairesinde veznedar olan ve bu görevi gereği vergi mükellefleri Akif Ş., Hasan İ., Recai K., Veysel K., Hüseyin K. ve Hasan K. tarafından vergi borçlarına karşılık yatırılması için kendisine verilen paralardan toplam 55.834.000 lirayı, mükelleflere verilen vergi alındılarının 1. nüshasını tahsil edilen gerçek miktara uygun, dairede kalan dip koçanlara ise daha düşük ve değişik mükelleflerin isimlerini yazarak kurum kayıtlarına intikal ettirmeyip uhdesinde bırakıp, bir müddet kullandıktan sonra bu meblağı ve 20.207.000 lira tutarındaki gecikme zammını olayın ortaya çıkarılmasından önce, 5.812.000 lira tutarındaki gecikme zammını da olay ortaya çıkarıldıktan sonra 10.04.1997 tarihinde kurum kayıtlarına intikal ettirdiği anlaşılan sanığın eyleminin mükelleflerden temin edilen vergi alındı makbuzlarının dairedeki nüshalarıyla karşılaştırılması gibi daire dışı kayıtlarla ortaya çıkarıldığı ve teselsül eden nitelikli kullanma zimmet suçunu oluşturduğu halde basit zimmet suçundan hüküm kurulması", Yargitay 5. CD, 30.04.1998 tarih ve E. 1998/1178 K. 1998/1768 sayılı karar1 için bkz. Baytemir, s. 178.

70 Selami Turabi, Zimmet Suçları, 1. Baskı, Seçkin Yayıncılık, 2012, s. 111; Baytemir, s. 60; Akkaş, s. 335.

71 Akkaş, s. 335.

72 "Kullanma zimmetinde, suçun konusunun kullanma ile elde olunan yarar(nema) olmas1 karşısında, bilirkişi tarafından hesaplanacak nemanın da ödenip ödenmediği araştırılarak sonucuna göre cezadan 248. Madde uyarınca indirim yapılması ve nema miktarı tespit edil- 
Failin aynı suç kastı kapsamında kullanma zimmetiyle beraber temel (temellük) zimmet suçunu işlediği hallerde, elde edilen nemanın dışında zimmete geçirilen malın değeri de dikkate alınarak değer tayin edilir. Sadece zincirleme kullanma zimmeti suçunun işlendiği halde ise failin elde etmiş olduğu toplam nema miktarı üzerinden bir değerlendirme yapılması gerekmektedir.

Türk Ceza Kanunu m. 249'un gerekçesinde belirtildiği üzere, zimmete geçirilen malın değerinin çok düşük olması durumunda failin tasarrufunun, hoşgörüyle karşılanabileceği belirtilmiştir. Müsamaha edilen zimmet ${ }^{73}$ olarak adlandırılan bu halde, zimmet suçunun oluşmadığ kabul edilmektedir. Ancak bu kabul, farklı gerekçelere dayandırılmaktadır. Suçun oluşmaması örf ve adete veya yerleşmiş uygulamalara ${ }^{74}$, fiilin haksızlık içeriğinin azlığına ${ }^{75}$ veya idarenin rızasının olmas ${ }^{76}$ gibi farklı temellere dayandırılmaktadır. $\mathrm{Bu}$ bakımdan gerekçede müsamaha edilen zimmetin de hem süre hem de kullanılış biçimi itibariyle kullanma zimmeti bakımından da geçerli olduğu belirtilmiştir.

Kullanan kişi açısından elde edilen nemanın çok az olduğu hallerde, kullanma zimmetinin oluştuğu söylenemez. Aslında ortada uygun olmayan, haksızlık meydana getiren bir kullanım söz konusuysa da ortaya çıkardığ1 haksızlık cezayı gerektirici bir boyutta olmamaktadır ${ }^{77}$. Kanun koyucunun da söz konusu suça yer verirken amaçladığı, kamu görevlisinin hemen her özel kullanımını cezalandırmak değildir. Önemsiz veya ağır olmayan fiillerin, soyut hukuk kurallarını somut olaylara uygulamak gibi bir görevi olan hâkim tarafından ceza hukukunun kapsamı dışına çıkarılması gerekmektedir ${ }^{78}$. Failin elde ettiği nemanın çok az olduğu hallerde oluşturduğu haksızlığın

dikten sonra şartların varlığı halinde değer azlığı sebebiyle 249. Maddenin uygulanıp uygulanmayacağı hususunun karar yerinde tartışılması gerektiğinin gözetilmemesi”, Yargitay 5. CD, 11.03.2019 tarih ve E. 2017/7018 K. 2019/2847 say1l karar1, <https://karararama. yargitay.gov.tr/> Erişim Tarihi 21 Ağustos 2020.

73 Bkz. Özgenç, Zimmet, s. 27.

74 Ayhan Önder, Türk Ceza Hukuku Özel Hükümler, 4. Bası, Filiz Kitabevi, 1994, s. 119; Dönmezer, s.83.

75 Özgenç, Genel Hükümler, s. 28; Özbek, Doğan ve Bacaksız, s. 1048.

76 Erem, s. 43.

77 Özgenç, Zimmet, s. 27.

78 Hakan Hakeri, “Ceza Hukukunda Önemsiz Hareketler”, 2007, (69), Türkiye Barolar Birliği Dergisi, s. 61, <http://tbbdergisi.barobirlik.org.tr/m2007-69-300> Erişim Tarihi 13 Aralık 2020. 
boyutu da önemsiz bir derecede kalmaktadır. Bu sebeple biz de kullanma zimmeti özelinde müsamaha edilen zimmet kavramının temelinde fiilin haksızlık muhtevasının az olması fikrine katılmaktayız. Zira ceza hukuku bakımından kişilerin gerçekleştirdiği her tipik, hukuka aykırı ve kusurlu fiilin cezalandırılması ceza hukukunun "ultima ratio" niteliği ile uyuşmaz ${ }^{79}$.

\section{Kullanma Zimmetinin Suçun Özel Görünüş Biçimleri Bakımından Değerlendirilmesi}

\section{A. Teșebbüs}

Teşebbüsle ilgili zimmet suçunun temel şeklinde olduğu gibi kullanma zimmeti bakımından da genel kurallar geçerlidir ${ }^{80}$ (TCK m. 35). Her ne kadar failin kastı kullanmaya yönelik olsa da kullanma zimmetinde de zimmet suçunun temel şeklinde olduğu gibi suç konusu malın failin zimmetine geçirildiği anda suç tamamlanır ${ }^{81}$.

Türk Ceza Kanunu'nun, “fail, suçun icra hareketlerinden gönüllü vazgeçer veya kendi çabalarıyla suçun tamamlanmasını veya neticenin gerçekleşmesini önlerse, teşebbüsten dolayı cezalandirllmaz; fakat tamam olan kısım esasen bir suç oluşturduğu takdirde, sadece o suça ait ceza ile cezalandırılır" hükmünü ihtiva eden m. 36'nın uygulanması üzerinde de durmak gerekir. Kullanma zimmetinde, malın geçici bir süreliğine kullanılmak için alınmasının gerekli olduğunu belirtmiştik. Bu esnada kişinin suçun icra hareketlerinden gönüllü olarak vazgeçmesi mümkündür. Örneğin, görevi sebebiyle zilyetliği kendisine devredilmiş olan belediyeye ait otobüsü mesai saatleri dışında kiralamaya çalışan kamu görevlisinin, kiralayacak kişi ile telefonda görüşmesinden sonra, yaptığının yanlış bir şey olduğunu düşünerek otobüsü kiralamak isteyen kimseye teslim etmemesi durumunda, gönüllü vazgeçme hükümlerinden faydalanması nedeniyle cezalandırılmaması gerekir.

\footnotetext{
79 Hakeri, Önemsiz Hareketler, s. 92.

80 "Sanığın depo memuru olup denetim ve sorumluluğunda bulunan orman emvalini faydalanmak için usulsüz olarak depodan çıkarıp İsmail'in hızar atölyesine sevk ettiği sırada alınan ihbar sonucu Orman İdaresi görevlilerince izlenip henüz kamyondan indirilmeden yakalanması ile açığa çıkan eyleminin icrai hareketlerinin tamamlanamaması karşısında zimmete eksik teşebbüs suçunu oluşturduğu gözetilmeden yazılı şekilde beraatine karar verilmesi”, Yargitay 5. CD, 05.02.1992 tarih ve E.1991/5125 K. 1992/405 sayılı kararı, <http://www. kazanci.com/kho2/ibb/giris.html> Erişim Tarihi 13 Aralık 2020.

81 Koca ve Üzülmez, Özel Hükümler, s. 984.
} 


\section{B. İştirak ve İçtima}

Teşebbüste olduğu gibi iştirak bakımından da genel kurallar geçerlidir. Buna göre, "suçun kanuni tanımında yer alan fiili birlikte gerçekleştiren kişilerden her biri, fail olarak sorumlu olur" (TCK m. 37/1). Kamu görevlisinin, bir başkasını kullanma zimmetinin işlenmesinde araç olarak kullanması da mümkündür (TCK m. 37/2, birinci cümle). Bu bağlamda örneğin, belediyeye ait kamyonu başkasına kiralayan fen işleri müdürünün, belediyeye ait bir işin yapılacağından bahisle kamyon şoförünü yanıltarak, kamyonun anlaştı̆̆ zimmetini dolaylı fail olarak işlediği kabul edilebilir. Zimmet suçunun kamu görevlileri tarafindan işlenen özgü bir suç olması ve bu nedenle sadece kamu görevlilerinin bu suçun faili olabilmesi ${ }^{82}$, kullanma zimmeti açısından da geçerlidir. Zira, "özgü suçlarda, ancak özel faillik niteliğini taşıyan kişi fail olabilir. Bu suçların işlenişine iştirak eden diğer kişiler ise azmettiren veya yardım eden olarak sorumlu tutulur" (TCK m. 40/2) ) $^{83}$.

Zimmet suçu ve konumuz özelindeki kullanma zimmetinin, görevi kötüye kullanma suçunun özel bir türü olması nedeniyle kullanma zimmetini işleyen kamu görevlisinin sadece bu suçtan dolayı sorumlu tutulması gerekir. Bunun haricinde kişinin genel bir suç olan görevi kötüye kullanma suçundan ayrıca sorumlu tutulması mümkün değildir ${ }^{84}$.

Kullanma zimmetinin aynı suç işleme kararı icrası kapsamında değişik zamanlarda işlenmesi durumunda, zincirleme suç hükümlerinin uygulanarak failin, tek bir kullanma zimmetinden sorumlu tutulmasi; ancak bu cezanın belli bir oranda arttırılması gerekir (TCK m. 43/1, üçüncü cümle). Farklı zamanlarda işlenen kullanma zimmetinin konusu, farklı kişilere ait ise failin bütün gerçekleştirilen fiillerden gerçek içtima hükümleri doğrultusunda ayrı ayr1 sorumlu tutulmasi gerekir ${ }^{85}$.

\footnotetext{
82 Koca ve Üzülmez, Özel Hükümler, s. 985.

83 “Zimmet suçu özgü suçlardan olup, kamu görevlisi olmayan sanıklardan Oğuz'un TCK'nın 40/2. maddesine göre, azmettiren veya yardım eden olarak sorumlu tutulacağının nazara alınmaması", Yargitay 5. CD, 16.02.2009 tarih ve E. 2008/9242 K. 2009/1799 sayıl1 kararı, <http://www.kazanci.com/kho2/ibb/giris.html> Erişim Tarihi 13 Aralık 2020.

${ }^{84}$ Koca ve Üzülmez, Özel Hükümler, s. 985.

85 Koca ve Üzülmez, Özel Hükümler, s. 986.
} 


\section{Kullanma Zimmeti Bakımından Etkin Pişmanlık Hükümlerinin Uygulanması}

Türk Ceza Kanunu m. 248'de zimmete geçirilen malın aynen iade edilmesi veya uğranılan zararın tazmin edilmesi, ödeme zamanı da dikkate alınarak zimmet suçuna ilişkin etkin pişmanlık hali olarak kabul edilmiştir ${ }^{86}$. Maddenin 1. fikrasına göre zimmet suçundan dolayı soruşturma başlamadan önce failin zimmete geçirdiği malı aynen iade etmesi veya uğranılan zararı tamamen tazmin etmesi halinde, verilecek cezanın üçte ikisinin indirileceği yer almaktadir.

Etkin pişmanlığın, soruşturma başladıktan sonra gösterilmesi de mümkündür. 2. fikrada failin soruşturma başladıktan sonra ancak henüz kamu davası açılmadan önce zimmete geçirdiği malı aynen iade etmesi veya uğranılan zararı tamamen tazmin etmesi halinde verilecek cezanın yarısının indirileceği belirtilmektedir ${ }^{87}$.

Kullanma zimmetinde failin etkin pişmanlı hükümlerinden faydalanabilmesi için elde ettiği nemayı(yarar) da iade etmesi gerekir. İade, zimmete geçirilen malın aslı ile bundan elde edilen nemanın tamamen iadesi ya da tazmin edilmesi şeklinde olacaktır ${ }^{88},{ }^{89}$. Teminat gösterilmesi, takas teklif

86 Baytemir, s. 72.

87 Burada sorun arz eden husus; ilgili hakkında idari bir soruşturmanın başlaması, fakat henüz adli bir soruşturmanın başlamaması ve bu esnada etkin pişmanlığın gösterilmesi durumunda, yapılacak indirimin nasıl belirleneceğidir. Kanımızca TCK m. 248'de kullanılan soruşturma ve kovuşturma kavramlarının teknik anlamda kullanıldığını ve bunlar ile kastedilenin 5271 sayılı CMK m. 2'de belirtilen soruşturma ve kovuşturma olduğunu kabul etmek gerekir. Zira kanun koyucu örneğin rüşvet suçuna ilişkin etkin pişmanlık hükmü olan m. 254 'te soruşturma ve kovuşturma yerine "durumun resmi makamlarca öğrenilmesi" ifadesini kullanmış, böylece ilgili hakkında idari bir soruşturmanın başlamasını etkin pişmanlık dolayısıyla yapılan indirimde etkili olmasını kabul etmiştir. Buna karşılık kanun koyucu TCK m. 248'de bilinçli olarak soruşturma ve kovuşturma kavramlarını kullanmıştır. TCK m. 248'in gerekçesinde geçen "etkin pişmanlı̆̆ın soruşturma başlatıldıktan sonra ve fakat henüz kamu davası açılmadan önce gösterilmesi de mümkündür” ifadesinden de anlaşıldığ üzere, kanun koyucunun kullandığ 1 soruşturma ve kovuşturma kavramları teknik anlamdaki soruşturma ve kovuşturmaya karş1lik gelmektedir.

88 Gökcan, s. 338.

89 "Kullanma zimmetinde geçici süreyle kullanılıp iade edilen paradan elde edilen nemanın suçun konusunu oluşturduğu, bu nedenle etkin pişmanlıktan yararlanmak için bu şekilde hesaplanan nema tutarının ayrıca ödenmesi gerektiği, olayımızda ise nema tutarının 17.10.2010 tarihinde yani kovuşturma aşamasında ödenmesi karşısında etkin pişmanlık yönünden TCK'nın 248/2- son cümlesi uyarınca cezadan indirim yapılması gerekirken 1. fikrasının uygulanması suretiyle eksik ceza tayini”, Yargitay 5. CD, 27.06.2013 tarih ve E. 2013/8743 K. 2013/7325 sayılı kararı, <https://karararama.yargitay.gov.tr> Erişim Tarihi 28 
edilmesi veya senet verilmesi tamamen iade veya tazmin yerine geçmez ${ }^{90}$. İştirak halinde işlenmiş olan kullanma zimmetinde, fail sadece kendisi üzerine düşeni iade veya tazmin ederek etkin pişmanlık hükümlerinden faydalanamaz ${ }^{91}$. Bununla birlikte iadenin malın alındığ 1 yere yapılmas 1 yeterlidir $^{92}$. Ayrıca iadenin gönüllü olarak gerçekleştirilmesi gerekir. Failin, iradesi dışında örneğin bir kolluk operasyonu sonrasında malın ele geçirilmesi durumunda etkin pişmanlık hükümlerinin uygulanmayacağı gayet açıtır.

Misli olmayan bir malın kullanılmak üzere alınması halinde, uğranılan zararın tespitinde, malın kullanımı boyunca elde edilen artı değerlerle malın kendisinde gerçekleşen değer kaybı dikkate alınmalıdır ${ }^{93}$.

\section{Yaptırım}

Kullanma zimmetinin cezasının, birinci fikradaki zimmet suçunun temel şekline göre belirleneceği hüküm altına alınmıştır (TCK m. 247/1). Somut olayda, failin işlediği fiilin öncelikle kullanma zimmetinin temel veya nitelikli şekli olmasına göre, TCK m. 61 hükümleri çerçevesinde temel ceza belirlenmeli; eğer somut olayda hâkim cezada indirim yapılması gerektiğine karar vermiş ise bu indirim m. 247/3 uyarınca, birinci fikraya göre belirlenen cezanın yarısına kadar olmalıdır. Dikkat edilirse kullanma zimmetinin söz konusu olduğu hallerde indirim yapılıp yapılmaması hâkimin takdirinde olan bir husustur. Hâkim, bu konudaki takdir yetkisini kullanırken somut olayın şartlarını göz önünde bulundurmalı, örneğin zimmete konu malın kamu için acil bir ihtiyaç teşkil edip etmediği, failin malı kullanım süresi gibi hususları dikkate almalıdır. Ancak, failin davranışlarının nitelikli kullanma zimmetine sebebiyet vermesi halinde, TCK $\mathrm{m}$. $61 / 3$ gereğince hileli davranışların, temel ceza belirlenirken dikkate alınmaması gerekir ${ }^{94}$. Hükmedilen cezanın kanunda belirlenen sınırlar içinde kalması ve diğer şartların da gerçekleşmesi durumunda, hükmün açıklanmasının geri bırakılması veya hapis cezasının

Temmuz 2020.

90 Volkan Aslan, “Zimmet Suçu”, 2013, 71(1), İstanbul Üniversitesi Hukuk Fakültesi Mecmuas1, s. 63, <https://dergipark.org.tr/tr/pub/iuhfm/issue/9188/115155> Erişim Tarihi 19 Kasim 2020.

91 Rezzan İtişgen, “Türk Hukukunda Zimmet Suçu”, 2013, 71(1), İstanbul Üniversitesi Hukuk Fakültesi Mecmuas1, s. 655, <https://dergipark.org.tr/tr/pub/iuhfm/issue/9188/115185> Erişim Tarihi 19 Kasım 2020.

92 Centel, s. 2795.

93 Akçin, s. 225.

94 Koca ve Üzülmez, Özel Hükümler, s. 989. 
infazının ertelenmesine karar verilebilir.

Kullanma zimmetinde, failin aldığ malın aslının ve elde edilen nemanın müsaderesine karar verilebilir. Ancak bu halde müsadere edilecek olan malvarlığı değerinin sahibine iade edilememesi gerekir. Oysa kullanma zimmetine konu olan mal ve elde edilen nemanın kamu idaresine veya iyi niyetli üçüncü kişilere iadesi mümkündür. $\mathrm{Bu}$ durum kullanma zimmeti açısından müsadere hükümlerinin uygulanmasını zorlaştırmaktadır. Ayrıca kullanma zimmeti suçunun, belli bir hak ve yetkinin kötüye kullanılması suretiyle işlenen kasıtlı bir suç olması sebebiyle fail hakkında TCK m. 53/5 çerçevesinde hak yoksunluğu da gündeme gelecektir ${ }^{95}$.

\section{Soruşturma ve Kovuşturma Usulü}

Kullanma zimmeti resen soruşturulan bir suç tipidir. $\mathrm{Bu}$ suça 3628 sayılı "Mal Bildiriminde Bulunulması, Rüşvet ve Yolsuzluklarla Mücadele Kanunu" ${ }^{96 "}$ kapsamında açıkça yer verilmese de suçun zimmet suçunun daha az cezay1 gerektiren bir nitelikli hali olduğu gözetilerek, kullanma zimmeti durumunda 4483 sayılı Memurlar ve Diğer Kamu Görevlilerinin Yargılanması Hakkında Kanun ${ }^{97}$ hükümlerinin uygulanmayacağ1 ve soruşturmanın Cumhuriyet savcıllğınca doğrudan doğruya ve bizzat yürütülmesi ile davanın açılacağı, genel ve temel bir ilke olarak kabul edilmiştir ${ }^{98}$. Kullanma zimmetiyle beraber başka suçların da işlenmesi durumunda, işlenen suçların kendi tabi olduğu soruşturma usulüne göre yapılması gerekir ${ }^{99}$. Soruşturmas1 izne tabi bir suçun, sırf kullanma zimmetiyle beraber işlendiğinden bahisle izin alınmaksızın soruşturulması söz konusu olamaz ${ }^{100}$.

Kullanma zimmeti suçunda görevli mahkeme, 5235 sayılı Adli Yargı İlk Derece Mahkemeleri ile Bölge Adliye Mahkemelerinin Kuruluş, Görev ve Yetkileri Hakkında Kanunun ${ }^{101}$ 12. maddesi uyarınca ağır ceza mahkemesidir.

\footnotetext{
95 Koca ve Üzülmez, Özel Hükümler, s. 989; Baytemir, s. 64.

964 Mayıs 1990 tarih ve 20508 sayılı Resmî Gazete' de yayımlanmıştır.

974 Aralık 1999 tarih ve 23896 sayılı Resmî Gazete' de yayımlanmıştır.

98 Akçin, s. 317.

99 Ahmet Ceylani Tuğrul, Öğreti ve Uygulamada Zimmet- Banka Zimmeti- İrtikap- Rüşvet Suçları, 2. Baskı, Seçkin Yayıncılık, 2013, s. 274.

100 Tuğrul, s. 274.

1017 Ekim 2004 tarih ve 25606 Resmî Gazete'de yayımlanmıştır.
} 


\section{Sonuç}

Zimmet suçu, kamu görevlisinin görevi sebebiyle kendisine bırakılan veya koruma ve gözetimi altındaki malı, zimmetine geçirmesi ile oluşmaktadır. Zimmete geçirme, failin mal üzerinde malik gibi tasarrufta bulunmasını ifade eder. Tasarruf, suça konu şeyin mal edinilmesi, amacı dışında kullanılması, tüketilmesi şeklinde olabileceği gibi malın bir başkasına satılması, verilmesi şeklinde de olabilir.

765 sayılı mülga Türk Ceza Kanunu döneminde kamu görevlisinin, görevi sebebiyle kendisine bırakılan malı geçici bir süre için hususi ihtiyaçlar doğrultusunda kullanması halinde sorumluluğunun ne olduğu konusunda belirsizlik bulunmaktaydi. Kullanma zimmeti olarak adlandirılan bu kavram, 765 sayılı mülga Türk Ceza Kanunu döneminde açıkça düzenlenmemesine rağmen doktrin ve uygulamada yer bularak, Yargıtay'ın faile verilen ağır para cezasının tespitinde kullanılmıştır. Ancak buna rağmen kullanma zimmeti bakımından açıkça bir hüküm yer almadığı için kavramın uygulanması somut olaylar bakımından belirsizlikler oluşturmuştur. 5237 Sayılı TCK'da yer alan kullanma zimmeti düzenlemesi ile suçun cezalandırılacağına dair bir tereddüt kalmamıştır.

Kullanma zimmetinde suçun konusu, failin kullanmak üzere zimmetine geçirdiği mal değil, malın kullanımı ile elde ettiği nemadır(yarar). Nema, failin kendisi veya üçüncü bir kişi için de olabilir. Failin malı tahsis amacı dahilinde veya bir kamu kurumunun yararına olacak şekilde kullanması durumunda, kullanma zimmeti oluşmaz. Malın kullanım süresi suçun oluşması bakımından önemsiz olsa da kullanımın nema elde edilebilecek kadar uzun olması gerekir.

Malın iade edilmek ve geçici bir süre için kullanılmak üzere alınması, zimmet suçunun temel şeklinden ayrılan bir nokta olarak karşımıza çıkmaktadır. Suçun tamamlanması için failin malı iade etmek üzere alması gerekmektedir. İadenin gerçekleşmesi, suçun oluşması bakımından önemli değildir. İade etme amacı mal alınmadan önce bulunmalı, kullanma süresince devam etmelidir. Failin kullanıp iade etmek üzere aldığı mal üzerinde sonradan mal edinme amacı ortaya çıkarsa faili zimmet suçunun temel şeklinden sorumlu tutmak gerekir.

765 sayı1ı TCK döneminde Yargıtay, zimmet suçunun temel şekli ile kullanma zimmetini ayırt etmek için iadenin yapıldığ zamanı esas alan bir uygulamayı benimsemiştir. Uygulamaya göre failin herhangi bir uyarı, şikâyet, denetim veya soruşturma olmaksızın, malın iadesini yapmış olması halinde, 
failin kastının kullanma zimmetine yönelik olduğu kabul edilmekteydi. Bu durumun aksine malın fail tarafindan şikâyet ya da soruşturma vb. sonrasında iade edilmesi halinde ise kişinin kastı mal edinme kabul ediliyor ve cezalandırma da buna göre yapılıyordu. Oluşan suçun belirlenmesinde manevi unsurun göz ardı edildiği bu uygulama, günümüzde de kabul görmeye devam etmektedir. Mevcut uygulama kullanma zimmetinde failin etkin pişmanlık hükümlerinden faydalanmasını zorlaştırmaktadır. Zira Türk Ceza Kanunu m. 248/2'ye göre, kovuşturma başlamadan önce failin gönüllü olarak zimmetine geçirdiği malı aynen iade etmesi veya uğranılan zararı tamamen tazmin etmesi halinde, verilecek cezanın indirileceği kabul edilmektedir. Yargitay uygulamasında ise malın sadece herhangi bir şikâyet ya da soruşturma vb. olmadan iadesi kullanma zimmeti kabul edildiğinden; failin iade etmek üzere kullandığı malı soruşturma evresinde iade etmesi temel zimmet kabul edilecek, kovuşturma öncesine ilişkin etkin pişmanlık hükümleri olan m. 248/2'nin uygulanmas1 somut olaylar bakımından imkânsız olacaktır. Kullanma zimmeti bakımından sadece soruşturma öncesindeki etkin pişmanlığı düzenleyen m. 248/1'in uygulanmas1 gündeme gelecektir. Kanaatimizce her somut olay kendi içerisinde değerlendirilerek, failin malı geçici bir süre için kullanıp iade etmek üzere aldığı hallerde kullanma zimmeti, mal edinme amaciyla zimmetine geçirdiği hallerde ise zimmet suçunun temel şeklinden sorumlu tutulması gerekir. Kastın belirlenmesinde şüpheye düşülmesi durumunda ise "şüpheden sanık yararlanır" ilkesi doğrultusunda kullanma zimmetinden cezalandırma yoluna gitmek daha doğru olacaktır.

Kanundaki düzenleniş şekli göz önünde bulundurulduğunda, kullanma zimmetinin de nitelikli olarak işlenebileceği kabul edilmelidir. Ancak nitelikli kullanma zimmeti suçunda, mal zaten failin egemenlik alanında olduğundan söz konusu hileli davranışlar suçun işlendiğini gizlemek için gerçekleştirilmektedir. Diğer taraftan zimmet suçuna ilişkin malın değerinin azlığı hükümleri, kullanma zimmeti bakımından da uygulanabilir. Bu noktada, kullanma zimmeti bakımından suçun konusu elde edilen nema olduğu için malın değerinin azlığ göz önüne alınırken nema esas alınmalıdır. Failin zincirleme kullanma zimmeti suçunu işlediği hallerde elde edilen toplam nema, malın değerinin azlığı bakımından değerlendirilir.

Elde edilen nemanın çok az olduğu hallerde, fail bakımından müsamaha edilen zimmet kavramının tartışılması gerekir. Failin kullanımı hem süre hem de kullanım şekli itibariyle bazı hallerde hoşgörüyle karşılanabilir. Kullanımın son derece kısa ve kayda değer bir nema elde edilmesine imkân vermediği 
hallerde suç oluşmaz. Zira failin gerçekleştirdiği fiilin meydana getirdiği haksızlık cezalandırmaya değer boyutta değildir. Ceza hukukunun "ultima ratio" özelliği itibariyle hemen her tipik, hukuka aykırı ve kusurlu hareketin cezalandırılması, cezadan beklenen adaletin elde edilmesine imkân vermez.

Kullanma zimmeti suçunu işleyen failin, etkin pişmanlık hükümlerinden faydalanabilmesi için zimmetine geçirdiği malın haricinde, ayrıca elde etmiş olduğu nemayı iade etmesi gerekir. İade, kullanmak üzere aldığı malın aslı ile nemasının tamamen geri verilmesi veya tazmin edilmesi şeklinde olacaktır.

\section{KAYNAKÇA}

Akçin İ, Kamu İdaresinin Güvenilirliğine ve İşleyişine Karş1 Suçlar, 2. Bask1, Adalet Yayınevi 2019.

Akkaş A, "Suç Konusu Malın Değerinin Azlığının Ceza Sorumluluğuna Etkisi”, 2018, 9(1), İnönü Hukuk Fakültesi Dergisi, s. 323-348, Erişim Tarihi 9 Ekim 2020.

Artuk M ve Gökcen A, Ceza Hukuku Özel Hükümler, 19. Baskı, Adalet Yayınevi 2021.

Aslan V, "Zimmet Suçu”, 2013, 71(1), İstanbul Üniversitesi Hukuk Fakültesi Mecmuası, s. 43-66, Erişim Tarihi 19 Kasım 2020.

Baytemir E, Açıklamal1-İçtihatlı Kamu İdaresinin Güvenilirliğine ve İşleyişine Karşı Suçlar ile Banka Zimmeti, 1. Baskı, Adalet Yayınevi 2011.

Centel N, “Zimmet Suçu”, 2019, 21(Özel S), Dokuz Eylül Üniversitesi Hukuk Fakültesi: Prof. Dr. Durmuş Tezcan’a Armağan, s. 2779-2800, Erişim Tarihi 15 Ekim 2020.

Donay S, "Türk Hukukunda Zimmet", 1968, 2(3), İstanbul Üniversitesi Mukayeseli Hukuk Araştırmaları Dergisi, s. 23-52, Erişim Tarihi 20 Aralık 2020.

Dönmezer S ve Erman S, Nazari ve Tatbiki Ceza Hukuku Genel Kısım Cilt: II, 12. Bası Beta Basım Yayım 1999.

Dönmezer S, Özel Ceza Hukuku Dersleri, Fakülteler Matbaası 1984.

Erem F, "Zimmet ve İhtilas", 1957, 14(1), Ankara Üniversitesi Hukuk 
Fakültesi Dergisi, s. 38-47, Erişim Tarihi 13 Mart 2020.

Gökcan H, Görevi Kötüye Kullanma, Zimmet, Banka Zimmeti, İrtikap, Rüşvet Suçları ve Kamu İdaresine Karşı İşlenen Suçlar, 1. Bask1, Seçkin Yayınc1l1k 2008.

Hafızoğulları Z ve Aygün Eşitli E, Kamu İdaresinin Güvenilirliğine Karşı Suçlar, 1. Baskı, US-A Yayıncılık 2014.

Hafızoğulları Z ve Özen M, Türk Ceza Hukuku Özel Hükümler Millete ve Devlete Karşı Suçlar, 1.Baskı, US-A Yayıncı1ık 2016.

Hakeri H, Ceza Hukuku Genel Hükümler, 22. Bask1, Adalet Yayınevi 2019.

Hakeri H, "Ceza Hukukunda Önemsiz Hareketler", 2007, (69), Türkiye Barolar Birliği Dergisi, s. 55-96, Erişim Tarihi 13 Aralık 2020.

İtişgen R, “Türk Hukukunda Zimmet Suçu”, 2013, 71(1), İstanbul Üniversitesi Hukuk Fakültesi Mecmuası, s. 639-672, Erişim Tarihi 19 Kasım 2020.

Koca M ve Üzülmez İ, Türk Ceza Hukuku Genel Hükümler, 12. Bask1, Seçkin Yayınc1lık 2019.

Koca M ve Üzülmez İ, Türk Ceza Hukuku Özel Hükümler, 7. Baskı, Adalet Yayınevi 2020.

Kütük C, Türk Ceza Hukukunda Zimmet Suçu, 1. Baskı, Seçkin Yayıncılık 2016.

Meran N, Zimmet- Rüşvet- İrtikap ve Görevi Kötüye Kullanma Suçları, 1. Baskı, Seçkin Yayıncılık 2008.

Okuyucu Ergün G, Türk Hukukunda Zimmet Suçu, 1. Bası, Çakmak Yayınevi 2008.

Önder A, Türk Ceza Hukuku Özel Hükümler, 4. Bası, Filiz Kitabevi 1994.

Özbek V, Doğan K ve Bacaksız P, Türk Ceza Hukuku Özel Hükümler, 15. Baskı, Seçkin Yayıncılık 2020.

Özen M, Öğreti ve Uygulama Işığında Ceza Hukuku Özel Hükümler, 3. Bask1, Adalet Yayınevi 2019.

Özgenç İ, Ekonomik Çıkar Amacıyla İşlenen Suçlar, 1. Baskı, Seçkin Yayınc1lık 2002. 
Özgenç İ, Türk Ceza Hukuku Genel Hükümler, 16. Bası, Seçkin Yayıncılık 2020.

Özgenç İ, Zimmet Suçu, 2. Bası, Seçkin Yayıncılık 2012.

Özkan H, Türk Ceza Kanunda Zimmet Suçu, 1. Baskı, Adalet Yayınevi 2013.

Sarsıkoğlu S, "Zimmet Suçunun Kooperatifler Kanunu ve Yardım Toplama Kanunu Özelinde Değerlendirilmesi”, 2013, (104), Türkiye Barolar Birliği Dergisi, s. 203-224, Erişim Tarihi 17 Aralık 2020.

Soyaslan D, Ceza Hukuku Özel Hükümler, 12. Baskı, Yetkin Yayınları 2018.

Tezcan D, Erdem M ve Önok R, Teorik ve Pratik Ceza Özel Hukuku, 18. Bask1, Seçkin Yayıncılık 2020.

Toroslu N, Ceza Hukuku Özel Kısım, 10. Baskı, Savaş Yayınevi 2019.

Tuğrul A, Öğreti ve Uygulamada Zimmet- Banka Zimmeti- İrtikap- Rüşvet Suçları, 2. Baskı, Seçkin Yayıncılık 2013.

Turabi S, Zimmet Suçları, 1. Baskı, Seçkin Yayıncılık 2012.

Üzülmez İ, "Yeni Türk Ceza Kanunu'nda Zimmet Suçu”, 2005, (5), Hukuki Perspektifler Dergisi, s. 216-225.

Yokuş Sevük H, Türk Ceza Hukuku Özel Hükümler, 2. Bask1, Adalet Yayınevi 2019.

https://www.ceza-bb.adalet.gov.tr/mevzuat/maddegerekce.doc

https://karararama.yargitay.gov.tr/

https://lib.kazanci.com.tr/yargitay

https://sozluk.gov.tr/ 
